\title{
Corporate Governance Indices and Construct Validity
}

\author{
(Draft May 2017)
}

\author{
Bernard Black \\ Northwestern University, Law School and Kellogg School of Management
}

Antonio Gledson de Carvalho

Fundacao Getulio Vargas School of Business at Sao Paulo

Vikramaditya Khanna

University of Michigan Law School

Woochan Kim

Korea University Business School

Burcin Yurtoglu

WHU - Otto Beisheim School of Management

European Corporate Governance Institute

Finance Working Paper No. 483/2016

Northwestern University School of Law

Law and Economics Research Paper No. 13-05

University of Michigan

Law and Economics Working Paper No. 2014-yy

This paper can be downloaded from the

SSRN electronic library at: http://ssrn.com/abstract=2838273

The Online Appendix can be downloaded from the

SSRN electronic library at: $\mathrm{http}: / / \mathrm{ssrn} \cdot \mathrm{com} / \mathrm{abstract}=\mathrm{xxxxxx \textrm {x }}$

Dataset and code availability:

The datasets and replication statistical code for this paper are available at: http://ssrn.com/abstract=

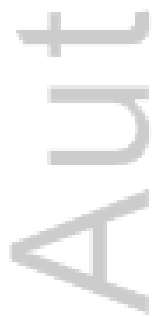

This is the author manuscript accepted for publication and has undergone full peer review but has not been through the copyediting, typesetting, pagination and proofreading process, which may lead to differences between this version and the Version of Record. Please cite this article as doi: $10.1111 /$ corg.12215

This article is protected by copyright. All rights reserved. 


\title{
Corporate Governance Indices and Construct Validity
}

\author{
ㄷ 2016 Bernard S. Black. All rights reserved.
}

\begin{abstract}
Manuscript Type: Conceptual and empirical.

Research Question/Issue: Many studies of firm-level corporate governance rely on aggregate "indices" to measure underlying, unobserved governance. But we are not confident that we know how to build these indices. Often we are unsure both as to what is "good" governance, and how one can proxy for this vague concept using observable measures. We conduct an exploratory analysis of how researchers can address the "construct validity" of firm-level governance indices, which poses a major challenge to all such studies.
\end{abstract}

Research Findings/Insights: We assess the construct validity of governance indices for four major emerging markets (Brazil, India, Korea, and Turkey), developed in prior work. In that work, we build country-specific indices, using country-specific governance elements that reflect local norms, institutions, and data availability, and show that these indices predict firm market value in each country. The use of country-specific indices puts great stress on the construct validity challenge of assessing how well a governance measure matches the underlying concept. We address here how well these four country-specific indices, and subindices for aspects of governance such as board structure or disclosure, measure unobserved, underlying actual governance quality.

Theoretical/Academic Implications: The construct validity of corporate governance indices should be addressed in research using these indices. We provide guidance on how researchers can do so.

Practitioner/Policy Implications: The uncertain construct validity of most corporate governance indices suggests caution in relying on research using these indices as a basis for firm-level governance changes, or country-level legal reforms.

Keywords: Corporate governance indices, construct validity, Brazil, Korea, India, Russia, Turkey, boards of directors, disclosure, shareholder rights, ownership structure.

JEL codes: G18, G30, G34, G39, K22, K29

* We thank Northwestern and Michigan Law Schools, Asia Institute of Corporate Governance, Corporate Governance Forum of Turkey, at Sabanci University (Istanbul), WHU - Otto Beisheim School of Management, and the International Finance Corporation for financial support. We are grateful to the Bovespa stock market, the Brazilian Comissao de Valores Mobiliarios, the Instituto Brasileiro de Governança Corporativa, and (Indian) National Stock Exchange and Bombay Stock Exchange, and the Indian Institute of Management, Bangalore, for supporting our survey efforts, and the Korea Corporate Governance Service for providing their survey results to us. We thank Yishay Yafeh (discussant), and participants in the Global Corporate Governance Colloquium (2016) for comments. Our Korea, Russia, and Turkey datasets and replication statistical code will be posted on the Social Science Research Network at http://ssrn.com/abstract=2503520. The Brazil, India, and pooled datasets are available from the authors to researchers who agree to maintain the needed confidentiality.

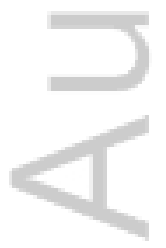




\section{INTRODUCTION}

A common strategy in research on firm-level corporate governance is to build corporate governance indices and then see whether they predict firm value or performance. These indices are imperfect, but their use is widespread because researchers lack good alternatives (Bhagat, Bolton and Romano, 2008). One concern with governance indices is what they actually measure. The concept of firm-level governance is abstract and latent rather than concrete and observable, and researchers are forced to proxy for this vague concept using observable measures. This raises concerns about the degree to which the proxy (a governance index) relates to the underlying concept it claims to measure (governance). The fit between the observable proxy or "construct" and the underlying concept is known as construct validity. ${ }^{1}$ This core issue is rarely addressed in corporate governance research.

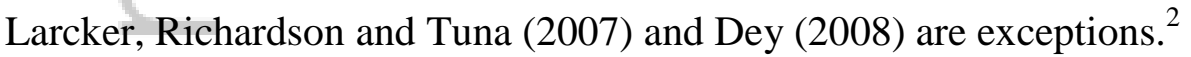

We discuss here what can usefully be said about which of the many possible

governance indices are sensible constructs, which are likely to do a reasonable job of measuring of what they intend to measure? We conduct here an exploratory analysis of how to tackle this question, using tools drawn from the causal inference, education and psychology literatures.

The often-used Gompers, Ishii and Metrick (2003) "G" index illustrates the central role that governance indices play in corporate governance research and why it is important to address issues of construct validity in index construction. They create a governance index with 24 equally weighted elements that measure takeover defenses and provide evidence that this construct predicts firm value and performance. Some of these elements are directly 
chosen by firms; others by the states where they incorporate. Bebchuk, Cohen, and Ferrell (2009) criticize this index and argue that only six firm-chosen elements, which they use to build their own "E" index, predict firm value and performance; the remainder are noise. Straska and Waller (2014) beg to differ, and report evidence that the 18 measures that Bebchuk, Cohen and Ferrell want to drop from the $\mathrm{G}$ index, treated as an "O" (for other) index, predict takeover likelihood. Karpoff, Schonlau and Wehrly (2016) build yet a different subset of the G-index elements, which they call the " $\mathrm{D}$ " index, that also predicts takeover likelihood. The confusion would be compounded if one considered takeover defense elements not in the original $\mathrm{G}$ index, or sought to build a broader governance index not limited to takeover defenses.

As the basis for our own analysis, we begin with our own prior work (Black et al. 2014 and 2016), in which we build governance indices in four major emerging markets (Brazil, India, Korea, and Turkey). In those studies, we argue that using a "common index" that relies on the same set of governance "elements" in each country - as massively multicountry studies typically $\mathrm{do}^{3}-$ is likely to yield poor constructs. As an example, consider board independence, often seen as a central component of corporate governance. Typical levels of board independence vary greatly across countries. Many Brazilian and Turkish firms have no independent directors at all. Korean firms are required to have a minimum of $25 \%$ independent directors, and Indian firms must have either a majority of independent directors or else at least one-third independent directors plus a non-executive board chair. Thus, a board structure element that asks whether a firm has one independent director is useful in Brazil and Turkey, but meaningless in India and Korea. Conversely, an 
element that asks whether a firm has a majority of independent directors is useful in India and Korea, but of limited value in Brazil and Turkey, where very few firms have a majority of independent directors. To use the fraction of independent directors as a governance element would also be misleading: the effect in Brazil and Turkey of firms moving from zero to one independent director may be very different from the effect of increasing the number of independent directors in India or Korea, where a minimum percentage is required by law.

As another example, consider audit committees. These committees might be important, but we cannot measure their value in countries such as India and Turkey, where all public firms must have an audit committee. In Brazil, many firms rely on a substitute local institution, the fiscal board, which is appointed by the shareholder's meeting rather than the board of directors. Only a minority of firms has an audit committee, and most of the firms with an audit committee have a fiscal board as well. The marginal contribution the audit committee makes to "governance" will thus be very different, and more nuanced, in Brazil than in other countries.

We pursue a different approach here and in our prior work. We recognize that the meaning of the same element will often differ across countries. We build different constructs in each country, that are likely to proxy for similar underlying governance aspects. More specifically, we first identify a limited number of general aspects of governance, using a combination of our own judgment, the available empirical evidence and such corporate governance theory as exists: board structure, disclosure, shareholders rights, related party transactions and ownership structure. Next, for each country, we identify elements (observable variables) that are "meaningfully" related to each of the general aspects. We treat 
an element $j$ as meaningful in country $i$ if: (i) element $j$ is often believed to correspond to good governance (sometimes with empirical support, but often not, given the current state of the governance literature); (ii) we judge, based on our own knowledge, that it is likely to be relevant to governance in country $j$; (iii) we have reasonably complete data on element $i$ across the firms in our country $j$ sample; (iv) there is reasonable variation in element $i$ across firms in country $j$; and (v) element $i$ is not too similar to another element that is also used in country $j$. Thus, the elements used in each country reflect a combination of local norms, local institutions and local data availability. We use these elements to build proxies for the general aspects of governance. We call these proxies "subindices." We then build each overall country governance index $(C G I)$ as an equally weighted average of the subindices. Manifestly, many other approaches to building indices are possible.

How well does a particular construct (a board structure subindex in a particular country, say) represent the corresponding general aspect of governance (board structure)? We cannot assess the validity of board structure subindex, seen as a construct, simply by asking whether this subindex empirically predicts an outcome of interest (we focus here on Tobin's q). If board structure subindex predicts the outcome, it could still be a poor construct, which is measuring something else-perhaps about "governance," perhaps not - or is simply correlated with an omitted variable which is the "true" predictor of the outcome. Board structure index could also be a useful construct, yet fail to predict the outcome because the underlying theory that posits a relationship between the general aspect (board structure) and the outcome is wrong. Therefore, predictive power is neither necessary nor sufficient, as a test for construct validity. 
We pursue here two approaches for assessing construct validity. First, we measure Cronbach's $\alpha$ scores, both for subindices (comprised of elements) and overall indices ${ }^{4}$ (comprised of subindices). Cronbach's $\alpha$ measures the inter-item correlation among the elements of an index. If the elements of a subindex collectively contribute to measuring the same general aspect of governance, one would expect those elements to be positively correlated and to yield a reasonably high Cronbach's $\alpha$. At the same time, overly high interelement correlations suggest that two elements are not sufficiently distinct and are capturing the same concept. Furthermore, if subindices in fact capture distinct aspects of governance, Cronbach's $\alpha$ across subindices cannot be extremely high.

Our second approach uses principal component analysis ${ }^{5}$ (PCA) as an alternative procedure to compute subindices. PCA consists of finding clusters (principal components) of related elements. Each component consists of a group of elements that correlate more among themselves than with other elements not belonging to that component. In this fashion, elements are aggregated according to their statistical properties rather than by prior leads from theory or previous empirical evidence. If our subindices (based on prior knowledge) are good constructs, one would expect that components will be loaded mostly or entirely of elements from a single subindex. We also perform regression analysis to test the predictive power of subindices vis-à-vis components.

We find in all four countries that overall indices that are calculated as the average of subindices present reasonable construct validity. Subindices in general have positive but moderate mean inter-subindex correlations suggesting that they capture different aspects of governance. At the same time, these correlations imply that any estimate of the effect of firm 
value or performance of a narrowly defined index, a single subindex, and even more so a single element such as board independence, is likely subject to omitted variable bias, due to omitting important aspects of governance. At the subindex level, we find that construct validity is reasonable in most cases, but is suspect for some subindices in some countries.

We focus here on the validity of firm-level corporate governance indices. We do not engage with the separate literature on country-level governance. However, efforts to build indices which measure country-level governance are likely to face similar issues. Consider, for example, an effort to measure creditor rights or shareholder rights (e.g., La Porta et al. (1998). The same formal legal rule could have very different effects. For example, the effect of formal shareholder rights could depend on the availability of derivative suits, or contingent fees for lawyers (Cheffins et al., 2008).

This paper is structured as follows: The next sections, in turn: (i) describe the data, samples and the variables; (ii) detail the two approaches, Cronbach's $\alpha$ and Principal Component Analysis (PCA), that we use to assess the construct validity of country indices; (iii) present and discuss our results: and (iv) provide a conclusion.

\section{SAMPLES, GOVERNANCE SURVEYS, AND INDICES}

\section{Sample Construction}

To build country governance indices, we rely on nonpublic data from firm surveys that were conducted in Brazil (2004, 2006, and 2009), India (2006, 2007, and 2012) and Korea (1998-2004), and public data hand-collected from firm annual reports in Turkey (2006-2012). This data collection effort greatly improves data quality compared to public data or commercial surveys, but also limits sample size and available years. We exclude 
state-controlled firms, subsidiaries of foreign companies and banks. Table 1 provides summary statistics for Brazil; the Appendix provides similar information for India, Korea, and Turkey. ${ }^{6}$

\section{[Table 1 about here]}

\section{Construction of Governance Indices}

Table 2 provides details on which potential Board Structure Subindex elements are available in each country. The Appendix provides an expanded table covering our full governance indices. The comparison of elements across countries illustrates why an index constructed using the same elements in each country is not meaningful, and why we instead build indices that rely on different elements in different countries. For instance, consider a minimum requirement for a "common" index of having only elements which are measurable in all four countries and, in our judgment, useful elements of a governance index in at least two of them. Such an index would have only 15 elements: 5 for board structure, 4 for disclosure, 2 each for board procedure and ownership; and one each for shareholder rights and RPTs. Of the 15 elements, 12 are useful in three countries, but none are useful in all four. Furthermore, as Black et al. (2014) show, this common index has no power to predict firm market value.

Most elements are dichotomous (coded as "1" if a firm has the attribute and "0" otherwise). $^{7}$ We normalize continuous variables to run from 0 to 1 . Table 2 also indicates which elements are non-public (available only from our surveys). For each element, it indicates in which countries the element is used and in which country it is either not available 
due to lack of data or not useful (forbidden, mandatory, too common, too rare or too similar to another element).

\section{[Table 2 about here]}

Within each subindex, we weight each element equally. Equal weighting of elements is a common practice when researchers build indices; doing so reflects our lack of knowledge about which elements are important (or more important); using equal weights also limits the temptation to engage in data mining when assigning weights. We then scale each subindex to run from 0 to 100 and take their average to compute the CGI. Table 3, Panel A, provides summary statistics for Brazil; the Appendix includes similar information for other countries. When running regressions one wants coefficients to be comparable across countries. Only for this purpose, we normalize each subindex to mean 0 and standard deviation 1 . Then, we sum the normalized subindices to create an overall country index. Finally, we normalize the country index to mean 0 and standard deviation 1 .

Data on particular elements is sometimes incomplete, so we need a procedure for dealing with missing values. Consider, for instance, a case in which there is one element missing out of four (e.g., Shareholder Rights in India). It does not seem reasonable to throw out the information provided by the three remaining elements. We use the following procedure: if data for a given element is missing just for a small number of firms, we compute the corresponding subindex as the average of the non-missing elements. Using this procedure, the sample does not increase at all in India; very little in Brazil (10 observations out of $158 ; 6 \%$ ), moderately in Turkey: from 998 to 1,199; 20\%); and substantially in Korea: (from 2,149 to 3,$098 ; 44 \%$ ). The numbers for Korea and Turkey show the importance of 
dealing with missing elements, rather than dropping these observations. In subindices with high mean inter-item correlations, our procedure is likely to introduce little bias, because missing information is substituted with "similar" information, however, if inter-item correlations within a subindex are low, using the information contained of the other elements may result into a considerable bias.

\section{[Table 3 about here]}

Table 3, Panel B, provides for each country the correlations between subindices, and the correlation between each subindex and the CGI. Since each subindex is mechanically correlated to the $C G I$ (each subindex is a component of country $C G I$ ), we also report the correlation between each subindex and the average of the other subindices (index complement). Country $C G I$ is correlated positively with each subindex; with correlation coefficients ranging from 0.19 (Ownership Structure in Korea) to 0.93 (Disclosure in Turkey). The correlations of subindices with their complements are generally positive, but

often much smaller and sometimes insignificant. They range from -0.09 (Ownership Structure in Korea) to 0.62 (Board Procedures in Turkey). For Brazil, India and Turkey, intersubindex correlations are also mostly positive and statistically significant (India has 2 negative correlations and Brazil has 1, but without statistical significance). Korea seems an exception because the Ownership Structure subindex correlates negatively with the other subindices.

It is worthwhile taking a more granular look at selected subindices. In Brazil, RPT Subindex correlates quite weakly with the other subindices. The low correlation is not inherently good or bad. The weak correlation could be a sign of a weak index that does not 
capture control of RPTs very well. But it could also indicate that the RPT Subindex is capturing an aspect of overall governance that is not well captured by any other subindex. We return to what we can say about which interpretation is more likely below, in the PCA analysis. For Korea, the negative correlation between Ownership Structure subindex and the other subindices suggests substitution between subindices: firms with strong scores on Ownership Subindex may choose governance structures which provide lower scores on other subindices.

The generally positive, and sometimes large inter-subindex correlations underscore the need to control for a broad measure of governance when assessing the predictive power of a particular aspect of governance. Failing to do so will lead to omitted variable bias (from omitting the remaining subindices).

\section{METHODOLOGY TO ASSESS CONSTRUCT VALIDITY}

In this section we present the two methods that we use to assess the internal validity of country subindices: Cronbach's $\alpha$ and Principal Component Analysis (PCA).

\section{Cronbach's Alpha}

Cronbach's $\alpha$ is a measure of the correlation between elements of a multipart measure and ranges from 0 to 1 . It is defined as:

$$
\alpha=\frac{n r}{1+(n-1) r}
$$

Here $n$ is the number of governance elements in the index and $r$ is the mean correlation among the elements. A "high" $\alpha$ provides evidence that the elements measure a similar underlying concept. Conversely, a "low" $\alpha$ provides evidence that the elements are not capturing a coherent underlying concept. As Equation (1) makes apparent, Cronbach's $\alpha$ 
measures whether the elements of a multipart measure correlate with each other. It does not - and cannot - directly assess how well the elements capture the underlying construct. Thus, a respectable $\alpha$ value can be seen as necessary, but not sufficient, for true construct validity.

Unfortunately, Cronbach's $\alpha$ has several important weaknesses. There is no simple measure for what counts as "high enough." One problem can be explained by analogy. Consider a test for general skill in mathematics. If the test consists solely of 20 problems in single-digit addition, measured $\alpha$ will be high, but this is only because one has, in substance, asked the same question 20 times. One must start instead with a conscious effort to ask different questions, covering different aspects of mathematical knowledge. For governance, one must choose elements which are not too similar to each other. If one succeeds, the interitem correlations should generally be positive, but not "too high."

For a test designed in this way, to ask different questions, rather than multiple variants of the same question, one rule of thumb from psychology is that $\alpha$ values above 0.7 are considered strong, and values above 0.6 are respectable (Kline, 2000). However, much of the education and psychology literature on Cronbach $\alpha$ ignores the sense in which high $\alpha$, driven by high inter-item correlation, might be a sign of test weakness, rather than strength. ${ }^{8}$

Cronbach's $\alpha$ has other weaknesses. First, as $n$ increases, $\alpha$ converges to 1 even if $r$ is low. In effect, one can get a high $\alpha$ from a few, strongly correlated elements, or from a larger number of elements, that correlate more weakly with each other. Second, with dichotomous elements, such as the elements of our governance indices, correlations tend to be small, yielding lower $\alpha$ values. ${ }^{9}$ 
With all these weaknesses, one might wonder why one should use this measure. We can offer several incomplete answers. First, the alternative of ignoring construct validity concerns is not appealing. Second, we do not have a better measure. Third, we do not use Cronbach's $\alpha$ alone. Instead we use several different approaches, to understand the apparent validity of our governance measures. In particular, we attend closely to inter-element and inter-subindex correlations, and also use PCA analysis.

\section{Principal Component Analysis}

Our second approach relies on PCA. In this approach, one creates eigenvectors (linear combinations of governance elements) based on the correlation matrix between governance elements (or subindices). These are usually termed "principal components." PCA is related to but distinct from "factor analysis." The vector with the largest eigenvalue is the first principal component; the vector with the second largest eigenvalue is the second component, and so on. One usually seeks to interpret the components with the largest eigenvalues, and ignores components with low eigenvalues. One rule of thumb is to retain components with eigenvalues greater than 1.0. But this is only a crude rule, because the more elements one starts with, the more eigenvectors will have eigenvalues above 1 .

In our setting, where we combine elements into subindices, one can construct principal components either as linear combinations of the subindices, or as linear combinations of the elements; we use both approaches. In forming principal components from elements, we examine the five components in each country with the highest eigenvalues. 
One typically tries to interpret each component by examining the elements with high "loadings" for that component. A rule of thumb in factor analysis (which has strong similarities to PCA) is to focus on elements with loadings greater than 0.4 (Costello and Osborne, 2005); we use this rule of thumb here. To interpret the retained principal components, it is common to rotate them. We use varimax rotation - a common choice, which preserves the orthogonality of the components, while maximizing the sum of variances of the squared loadings (Joliffe, 2002: 269). Varimax rotation often results in principal components which are easier to interpret than alternative rotations.

\section{Panel Data Analyses}

Our outcome variable is Tobin's $q$, which is the ratio of the market value to the book value of a firm's assets. Tobin's $q$ is a common outcome in "governance-to-value" studies. It is a measure of the value of minority shares, and does not capture any extra value of the control block. Tobin's $q$ can be used to measure the value added by corporate governance; the idea is that better governance leads investors to ascribe higher value to the same assets. Some governance aspects can also redistribute value between controllers and minority shareholders, without affecting overall firm value. Tobin's $q$, is itself an often-criticized construct; it remains commonly used because there is no good replacement. In this study, we employ it as a reasonable proxy for the value effects of firms' governance choices.

To reduce the influence of high- $q$ outliers, we use the natural logarithm of $q$ and also exclude outliers (year by year), for which if a studentized residual from regressing $\ln$ (Tobin's $q$ ) on country the $C G I>|1.96|$. To limit reverse causation, in which changes in Tobin's $q$ 
lead to changes in governance, we measure governance in the first part of a year and Tobin's $q$ at year-end.

We run firm fixed effects (FE) regressions in each country using an unbalanced panel. The firm FE model is well-known (e.g., Wooldridge, 2010, § 10.2) We review here selected aspects that are relevant for our study; see Black et al., 2014, 2016, for more details. The model is:

$$
\ln \left(q_{i, t}\right)=\beta_{0}+\boldsymbol{\beta}_{1} \times \mathbf{C G I}_{i, t}+\boldsymbol{\beta}_{2} \times \mathbf{x}_{i, t}+g_{t}+f_{i}+\varepsilon_{i, t}
$$

Here $\mathbf{C G} \mathbf{I}_{\mathrm{i}, \mathrm{t}}$ is either an overall country governance index or a vector of subindices; $\mathbf{x}_{\mathrm{i}, \mathrm{t}}$ is a vector of covariates, which we assume to be exogenous. The Appendix provides covariate definitions and indicates which covariates are available in each country. The $g_{\mathrm{t}}$ are year dummies and the $f_{\mathrm{i}}$ are firm effects. Exogeneity requires, among other things that current country governance indices do not influence future $\mathbf{x}$ 's. This is unlikely to be strictly true, but may be a reasonable approximation, especially with firm effects. Prior studies find that time varying firm characteristics only weakly predict governance. ${ }^{10}$ Bhargava and Sargan (1983) suggest that assuming exogeneity is more reasonable if one uses a random effects or fixed effects specification to address unobserved heterogeneity, if the data has a "short" time dimension, and a time-persistent variable of interest. Both fixed effects and random effects will be inconsistent if there are omitted time-varying firm covariates that are correlated with both governance indices and Tobin's $q$.

Exogeneity also requires that the current outcome variable $\ln \left(q_{\mathrm{i} . t}\right)$ does not influence future governance or x's. Greiser and Hadlock (2016) provide evidence that this assumption 
may not be satisfied in many corporate finance studies and discuss how one might test this assumption; doing so is beyond the scope of this project.

Subject to these exogeneity requirements, the firm FE estimator is consistent even if the firm effects are correlated with country governance indices and other covariates. However, fixed effects estimates rely only on within-firm variation over time, which reduces power. Since governance often changes slowly over time, the loss of power can be substantial. One also cannot use FE to study aspects of governance with little time variation, notably ownership structure.

We address the potential for correlated standard errors by clustering at the firm level, which allows for correlation within firms, across time.

\section{RESULTS AND DISCUSSION}

\section{Cronbach's $\alpha$ and Mean Correlations}

Assessment for Overall Governance Indices. Table 4 reports information on Cronbach's $\alpha$ and mean inter-item correlations. Panel A considers the governance elements individually (not combined into subindices). Cronbach $\alpha$ values range from 0.70 in India to 0.86 in Turkey. These are reasonably strong values. However, mean inter-element correlations range from 0.05 in India to 0.10 in Turkey. Thus, the strong $\alpha$ scores are driven by a substantial number of elements (ranging from 27 in Korea to 44 in Turkey) rather than high inter-element-correlations.

\section{[Table 4 about here]}

Figure 1 provides a histogram showing the frequency distribution of pairwise correlations of governance elements for Brazil (43 elements); the Appendix provides similar 
histograms for the other countries. For Brazil correlations are in the range of $[-0.62,0.87]$, but only a few have absolute values exceeding 0.5 and most are between -0.25 and +0.25 . The mean (median) absolute value is $0.13(0.08)$. The mean and median pairwise correlations for India and Korea are similar. ${ }^{11}$ The Turkey correlations are larger; the mean (median) absolute values is $0.22(0.13)$, and around $16 \%$ of the correlations exceed $0.5 .^{12}$ Most pairwise correlations are relatively small because most governance elements are binary and because, in choosing elements, we excluded potential elements that were too similar to each other. The generally low correlations, combined with relatively strong Cronbach $\alpha$ values, suggest that, as we intended in building the indices, the elements capture different aspects of corporate governance.

\section{[Figure 1 about here]}

We also investigate Cronbach's $\alpha$ and inter-item correlation for the overall governance indices, treating them as composed of subindices, rather than individual elements (Table 4, Panel B). Since subindices seek to capture different aspects of governance, one would hope for intermediate correlations. Conversely, high inter-index correlations might suggest that some subindices are measuring similar underlying constructs, and should perhaps be combined. Cronbach $\alpha$ values are smaller than in Panel A, even though the mean correlation is larger, due to the small number of subindices. Brazil, Korea, and Turkey have respectable $\alpha$ values, ranging from 0.50 to 0.58 . India, however, is a noticeable laggard: 0.31 . Most but not all inter-subindex correlations are positive, the mean absolute value ranges from 0.18 to 0.22 for Brazil, Korea, and Turkey, but is only 0.08 in India. 
The Cronbach $\alpha$ exercise can inform one's assessment of the construct validity of the overall governance indices. For Brazil, Korea, and Turkey, our judgment is that the overall indices appear to be reasonable constructs. In contrast, for India, the lower subindex-based $\alpha$ score and low inter-subindex correlations provide a warning that construct validity is likely low for the India Corporate Governance Index, and should prompt investigation of why this might be and what, if anything, researchers might do about this.

Assessment for Subindices. In Panels C-H of Table 4, we focus on the construct validity of the subindices. If the subindices are well-designed, we hope to find intermediate $\alpha$ values for elements within a single subindex. High $\alpha$ values suggest that elements are too similar to each other; low values suggest that they are not capturing a similar underlying concept. In fact, Cronbach's $\alpha$ values are smaller than for the overall indices. This is expected due to the smaller number of elements in each subindex. However, most $\alpha$ values are reasonably high. They range from 0.11 for India Shareholder Rights to 0.86 for Turkey Disclosure; 5 of the 19 subindex $\alpha$ values are above 0.7 ; and 10 values are above 0.6. Only India Shareholder Rights Subindex has $\alpha$ below 0.3. Some of the lower observed $\alpha$ 's result from a small number of measurable elements, either because data is not available, or because regulation that limits firms' governance choices.

Most subindices also have reasonable mean inter-element correlations, ranging from 0.03 for India Shareholder Rights to 0.36 for India RPTs. The correlations are between 0.30 and 0.36 for 3 of the pairwise comparisons; between 0.20 and 0.29 for 6 more; between 0.10 and 0.19 for 6 pairs; and 0.09 for the remaining 4 pairs ( 3 of these pairs are from India). 
This evidence suggests that most subindices, for most countries, are reasonable constructs. At the same time, this analysis suggests caution in relying on at least some subindices as good measures of underlying governance aspects. For example, the low Cronbach's $\alpha$ value for India Shareholder Rights suggests that this subindex is a poor construct. At the other extreme, Turkey Disclosure has a high Cronbach's $\alpha$ of 0.86 . This high $\alpha$ is driven mostly by a large number of elements (23), rather than a large inter-element correlation $(0.21)$; this combination suggests that this subindex provides a good measure of overall firm disclosure choices.

Lessons from Cronbach's $\alpha$ Analysis. The main lessons from our analysis of Cronbach's $\alpha$ and mean inter-item correlations include:

(i) Our procedure for building indices and subindices yield reasonable constructs in most cases, but construct validity can be less satisfactory for specific countries and subindices (for us, mostly in India).

(ii) In assessing construct validity, one should consider both Cronbach's $\alpha$ and inter-item correlations, with the ideal being to obtain intermediate interelement correlations (high values suggest failure to choose distinct elements or subindices; while low values suggest that the items may not capture a coherent underlying construct.

(iii) Since correlations among elements of subindices are relatively low, subindices with only a few elements increase the risk that one is not measuring well the intended general governance aspect. 
(iv) The low correlations between subindices suggest that to measure overall governance, one needs a broad index; conversely, an index for a particular aspect, such as board independence, is a poor measure of overall governance.

\section{Principal Component Analysis}

In Table 5, we present results for subindices for all four countries (Panel A), and element-level results for Brazil (Panel B). Appendix Table 5 presents element-level results for the other countries.

Consider first the subindex results in Panel A. We report only principal components with eigenvalues above 1.0 ("retained components"). There are two retained components for Brazil, India, and Turkey, and one retained component for Korea. The second column in Panel A reports the eigenvalues; the third reports the fraction of total variance explained by the component; remaining columns show the loading of each subindex for the retained components. For Brazil, Component 1 loads heavily on Disclosure, but also substantially on all other subindices except RPTs. Component 2 loads mainly on Ownership Structure. RPTs does not load on either component, suggesting that it is not important in explaining variation in governance across firms. For India, Component 1 loads on Board Structure, Board Procedure and RPTs, while Component 2 loads on Board Procedure, Disclosure and Shareholder Rights. For Korea, there is only one retained component, which loads broadly on Board Structure, Board Procedure, Disclosure and Shareholder Rights. For Turkey, Component 1 loads broadly on Board Structure, Board Procedure, Disclosure and Shareholder Rights; Component 2 loads on Ownership Structure. 
Thus, for all four countries, the first retained component loads (has loadings $>0.4$ ) on either three or four subindices. This suggests that the subindices collectively capture a coherent underlying concept. ${ }^{13}$ Only RPTs in Brazil and Ownership Structure in Korea do not load on any retained component. Thus, PCA analysis points in the same direction as Cronbach's $\alpha$ : to capture overall corporate governance one needs to consider a broad set of general aspects of governance. Furthermore, the portion of the variance explained by the retained factors is never above $62 \%$, suggesting that the retained components do not capture the full richness embedded in the subindices.

\section{[Table 5 about here]}

In Panel B, we focus on Brazil. We report only the 5 components with the highest eigenvalues, which we term the "main" components. The first principal component for Brazil loads on nine elements, of which eight are within Disclosure Subindex. This suggests that there is coherence to the Disclosure Subindex - its elements tend to load together. The second principal component loads on four elements, all within Shareholder Rights Subindex; the third principal component loads on four elements of RPT Subindex; the fourth component on three elements of Board Structure, and the fifth component on three elements of Ownership Structure. This pattern suggests that there is coherence to the subindices. In contrast, if the strongest principal components loaded on elements of multiple subindices, this would suggest that the subindices are poorly designed, and do not capture coherent aspects of governance. The 5 main components together load on all five Brazil subindices, supporting the need for a broad overall governance index. 
Each of the five main components loads on at least 3 elements, suggesting that individual elements do not capture much of the total variance in governance. These five components explain $41 \%$ of variance. The remaining 8 components with eigenvalues $>1$ explain another $29 \%$ of variance, which leaves $30 \%$ unexplained. This provides evidence that one needs a broad index to capture firm-level variation.

Lessons from the Principal Component Analysis. Our main conclusions from the PCA analysis are:

(i) Most of the main components load on elements of one or two subindices rather than having loadings that are scattered across three or more subindices (Korea, with results reported in the Appendix, is an exception). This suggests that the subindices are measuring distinct, consistent constructs.

(ii) Components of several different subindices load for one or more of the main components, suggesting that a narrow index will not capture overall governance well.

(iii) The elements of some subindices (Board Structure and Shareholder Rights in India, and Board Procedures and Ownership Structure in Turkey) do not load in any of the main components. This creates doubt whether these subindices capture any relevant underlying concept.

(iv) Most main components do not load on a single element (the exception is two components in Turkey, see Appendix). This reinforces the idea that one cannot capture a general aspect of governance with a single element. 
The PCA results can also suggest the value of breaking a subindex into subsubindices. For example, Board Structure Subindex might be divided into sub-subindices for Board Independence and Board Committees; and Disclosure Subindex might be divided into sub-subindices for financial and non-financial disclosure. The PCA analysis can guide the not-always-obvious decisions on which element belongs best in which sub-sub-index. We used our exploratory analysis in this way; it led us to modify Turkey Board Structure Index.

A further lesson from both the Cronbach's $\alpha$ and PCA analyses involves the design stage of a project that uses governance indices, when one is building an index and subindices, without yet assessing what outcomes the index may predict. Warning signs about low within-subindex or across subindex correlations provided by a Cronbach's $\alpha$ analysis, and about limited variation and subindex coherence from a PCA analysis, can suggest the need to rethink the index. One can search for additional useful elements, and consider discarding suspect elements.

\section{Governance and Firm Value}

In this section, we report results from firm FE analyses of whether governance predicts Tobin's $q$. For each country, we compare results using (i) our subindices, and (ii) the main principal components as predictors. Table 6 reports our regression analysis, omitting the coefficients on the covariates, year dummies and the constant term. Panel A reports the analysis using principal components as regressors (for technical reasons, we can use only firm-year observations with no missing governance elements). Panel B uses the same sample but switches to subindices as regressors. Panel C is similar to Panel B but divides Board Structure Subindex into Board Independence and Board Committees subsubindices. 


\section{[Table 6 about here]}

Panel A shows that in every country the first principal component significantly and positively predicts firm value (Tobin's $q$ ). Component 1 loads on Disclosure Subindex in Brazil, India, and Turkey, and on Board Structure Subindex in Korea. Component 2 takes a positive coefficient in all four countries but is statistically significant only in Korea; the Korea second component loads on Disclosure and Board Procedure subindices. All other main components are statistically insignificant.

Panel B reports regression results. ${ }^{14}$ The subindex results are substantially stronger than the PCA results for related principal components. For example, in Turkey, we go from a barely significant result for Component 1 , which loads on Disclosure [coeff. $=0.032 ; t=$ 2.04] to a stronger result for Disclosure Subindex [coeff. $=0.066 ; t=2.79$ ]. In Brazil and Korea, we also get sharper results for Disclosure Subindex than for the principal components which loads on Disclosure elements. ${ }^{15}$ In Korea, the results for Board Structure Subindex in Panel $\mathrm{C}$ are statistically stronger $(t=4.61)$ than those for Component 1 , which loads on board structure $(t=3.86)$. Thus, while the PCA results in Panel A are useful, and suggest the construct validity of the subindices, they are not a good substitute for the subindices in predicting Tobin's $q$. The subindices contain value-relevant information that related principal components do not. ${ }^{16}$

From Panel B, we obtain a consistent result that Disclosure matters and a less consistent result that Board Structure might also matter. The results for Board Structure could be mixed due to how we built this subindex - which combines board independence and board committee elements. At this point, The PCA analysis suggests that these two sets of 
elements should perhaps be separated. In Brazil, Component 4 loads on three Board Structure elements, all of involving board independence; in Korea, Components 1 and 3 load on six Board Structure elements, four of which relate to board independence; and in Turkey, Component 2 loads on four Board Structure elements, three of which relate to board independence. This suggests that it might be useful to separately assess board independence and board committee elements. Panel $\mathrm{C}$ therefore reports regression results after splitting Board Structure Subindex into sub-subindices for Board Independence and Board Committees. This panel provides stronger evidence that board independence predicts higher firm value. Board Independence Sub-subindex takes a positive, statistically significant coefficient in Korea and Brazil, and is marginally significant in Turkey. The exception is India, which has high minimum board independence requirements. Our Board Independence sub-subindex can capture only variation above those minimums, which might be unimportant to firm value. In contrast, Board Committees sub-subindex is positive and significant only for Korea, and indeed takes a negative coefficient for Brazil and Turkey.

\section{CONCLUSION}

Studies of firm-level corporate governance frequently rely on indices which are assumed to capture an underlying corporate governance aspect. However, the construct validity of these indices is rarely addressed. This paper is a first attempt to investigate how the construct validity of firm-level governance indices can be assessed, and what one can learn about index construction from that effort. We study the construct validity of firm-level indices in four major emerging markets: Brazil, India, Korea, and Turkey. We do so at two levels: for overall governance indices, comprised of subindices, which are comprised of governance 
elements, and for subindices, comprised of elements. We use three principal measures: Cronbach's $\alpha$; inter-item correlations; and PCA. The overall indices generally appear to provide reasonable construct validity. The mean correlations across subindices are moderate, suggesting that the subindices in fact capture different aspects of governance. Conversely, these correlations suggest that inference from a narrow index, a single subindex, or, even worse, a single element, likely suffers from omitted variable bias, because of the omission of important aspects of governance.

At the subindex level construct validity in often reasonable, but we find exceptions, where one has less confidence that a subindex is measuring a coherent underlying governance aspect. India Shareholder Rights Subindex is an example. One can also use the construct validity analysis as a guide to how to build indices and subindices. We rely on that analysis to guide an effort to divide Board Structure Subindex into sub-subindices for Board Independence and Board Committees.

We find that regressions of outcome variables (we focus here on Tobin's $q$ ) on principal components, while informative, are not a substitute for regressions on carefully built subindices. Instead the subindices often have greater statistical power in predicting Tobin's $q$.

Our exploration of construct validity for particular indices leaves a number of areas for future research. One is the application of our approach to construct validity to country-level governance indices, rather than the firm-level indices we examine here. Another involves how indices are built. In this project, we built the indices first, and then sought to assess 
whether the constructs were sensible. One could, however, readily imagine embedding the assessment of construct validity into index construction.

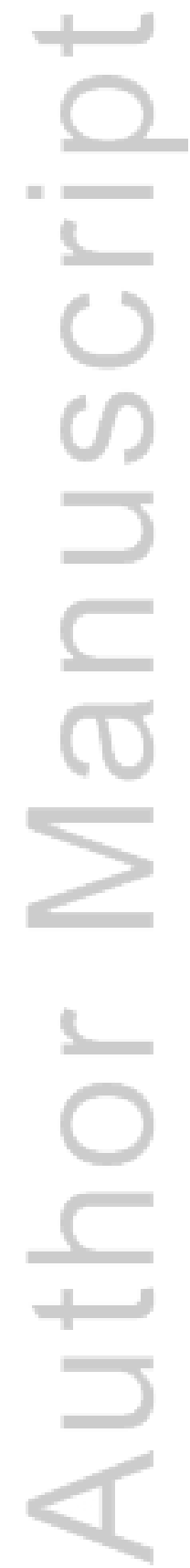

This article is protected by copyright. All rights reserved. 


\section{References}

Aggarwal, R., Erel, I., Stulz, R.M. \& Williamson, R. 2009. Differences in governance practices between U.S. and foreign firms: Measurement, causes, and consequences. Review of Financial Studies, 22: 3131-3169.

Amihud, Y., Schmid, M. \& Solomon, S.D. 2016. Do staggered boards affect firm value? Working paper.

Ararat, M., Black, B.S. \& Yurtoglu, B.B. 2016. The Effect of Corporate Governance on Firm Value and Profitability: Time-Series Evidence from Turkey, working paper, at http://ssrn.com/abstract=2703715.

Aslan, H., \& Kumar, P. 2014. National Governance Bundles and Corporate Agency Costs: A CrossCountry Analysis, Corporate Governance: An International Review 22: 230-251

Bebchuk, L.A., Cohen, A. \& Ferrell, A. 2009. What matters in corporate governance? Review of Financial Studies, 22: 783-827.

Beekes, W., Hong, A. \& Owen, S. A. 2010. An alternative measure of corporate governance using discrete principal component analysis. SSRN: http://ssrn.com/abstract=1623005.

Bhagat, S., Bolton, B. \& Romano, R. 2008. The promise and peril of corporate governance indices. Columbia Law Review, 108: 1803-1882.

Bhargava, A. \& Sargan, J.D. 1983, Estimating dynamic random effects models from panel data covering short time periods. Econometrica, 51: 1635-1660.

Black, B. 2001. The corporate governance behavior and market value of Russian firms. Emerging Markets Review, 2: 89-108.

Black, B. \& Vikramaditya K. 2007. Can corporate governance reforms increase firms' market values? Event study evidence from India. Journal of Empirical Legal Studies, 4: 749-796.

Black, B., Carvalho, A.G.d., Khanna, V, Kim, W. \& Yurtoglu, B.B. 2014. Methods for multicountry studies of corporate governance: Evidence from the BRIKT countries. Journal of Econometrics, 183: 230-240.

Black, B., Carvalho, A.G.d., Khanna, V, Kim, W. \& Yurtoglu, B.B. 2016. What aspects of corporate governance matter in emerging markets. SSRN: http://ssrn.com/abstract=2227718.

Black, B., Jang, H. \& Kim, W. 2006. Does corporate governance affect firms' market values? Evidence from Korea. Journal of Law, Economics and Organization, 22: 366-413.

Black, B., Love, I. \& Rachinsky, A. 2006. Corporate governance indices and firms' market values: Time-series evidence from Russia. Emerging Markets Review, 7: 361-379.

Briggs, S. R. \& Cheek, J. M. 1986. The role of factor analysis in the evaluation of personality scales, Journal of Personality, 54: 106-148.

Cheffins B., \& Black, B., Outside director liability across countries, Texas Law Review 84: 13851480 (2006). 
Cheung, Y-L., Connelly, T., Limpaphayom, P. \& Zhou, L. 2007. Do investors really value corporate governance? Evidence from the Hong Kong market. Journal of International Financial Management \& Accounting, 18: 86-122.

Claessens, S. \& Yurtoglu, B.B. 2013. Corporate governance in emerging markets: A survey. Emerging Markets Review, 15: 1-33.

Clark, L. A. \& Watson, D. 1995. Constructing validity: Basic issues in objective scale development. Psychological Assessment, 7: 309-319.

Costello, A.B. \& Osborne, J.W. 2005. Best practices in exploratory factor analysis: Four recommendations for getting the most from your analysis. Practical Assessment, Research \& Evaluation, 10: 1-9.

Dey, A. 2008. Corporate governance and agency conflicts. Journal of Accounting Research, 46: 1143-1181.

Doidge, C.G., Karolyi, A. \& Stulz, R.M. 2007. Why do countries matter so much for corporate governance. Journal of Financial Economics, 86, 1-39.

Durnev, A. \& Kim, E.H. 2005. To steal or not to steal: Firm attributes, legal environment, and valuation. Journal of Finance, 60: 1461-1493.

Gompers, P., Ishiee, J. \& Metrick, A. 2003. Corporate governance and equity prices. Quarterly Journal of Economics, 118: 107-155.

Grieser, W. \& Hadlock, C. 2016. Panel data estimation in finance: Preliminary assumptions and parameter consistency, SSRN: http://ssrn.com/abstract=2759386.

Horst, P. 1966. Psychological measurement and prediction. Belmont CA: Wadsworth.

Joliffe, I.T. 1995. Rotation of principal components: Choice of normalization constraints. Journal of Applied Statistics, 22: 29-35.

Jolliffe, I.T. 2002. Principal component analysis. New York, NY: Springer-Verlag.

Kaiser, H.F. 1958. The varimax criterion for analytical rotation in factor analysis. Psychometrika, 23: $187-200$.

Karpoff, J., Schonlau, R. \& Wehrly, E. 2016. Do takeover defenses deter takeovers? SSRN: http://ssrn.com/abstract=2608759.

Klapper, L.F. \& Love, I. 2004. Corporate governance, investor protection and performance in emerging markets. Journal of Corporate Finance, 10: 703-728.

Kline, P. 2000. Handbook of psychological testing. New York, NY: Routledge.

La Porta, R., Lopez-de-Silanes, F., Shleifer, A., Vishny, R. 1998. Law and finance. Journal of Political Economy, 106:1113-1155

Larcker, D.F., Richardson, S.A. \& Tuna, I. 2007. Corporate governance, accounting outcomes, and organizational performance. The Accounting Review, 82: 963-1008.

This article is protected by copyright. All rights reserved. 
Lei, A.C.H. \& Song, F.M. 2012. Board structure, corporate governance and firm value: Evidence from Hong Kong. Applied Financial Economics, 22: 1289-1303.

Linck, J.S., Netter, J.M. \& Yang, T. 2008. The determinants of board structure. Journal of Financial Economics 87: 308-328.

Nunnally, J.C. \& Bernstein, I.H. 1994. Psychometric theory. New York, NY: McGraw-Hill, Inc.

Shadish, W., Cook, T. \& Campbell, D. 2002. Experimental and quasi-experimental designs for generalized causal inference. Boston New York: Houghton Mifflin Company.

Straska, M., \& G. Waller (2014), Antitakeover provisions and shareholder wealth: A survey of the literature, Journal of Financial and Quantitative Analysis, 49: 933-956.

Strauss, M.E. \& Smith, G.T. 2009. Construct validity: Advances in theory and methodology, Annual Review of Clinical Psychology, 5: 1-25.

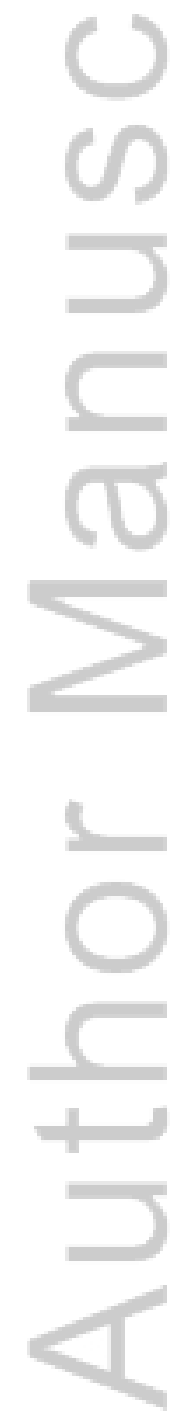

This article is protected by copyright. All rights reserved. 
TABLE 1

Summary Statistics for Brazil Sample

\begin{tabular}{|c|c|c|c|c|}
\hline Survey year & Public firms & $\begin{array}{c}\text { Responding } \\
\text { firms ( } \% \text { of public } \\
\text { firms) }\end{array}$ & $\begin{array}{l}\text { Market cap } \\
\text { (US\$ billions) }\end{array}$ & $\begin{array}{l}\text { Capitalization of } \\
\text { responding firms ( } \% \\
\text { of public firms) }\end{array}$ \\
\hline 2004 & 261 & $63(24 \%)$ & 524 & $260(49 \%)$ \\
\hline 2006 & 233 & $92(39 \%)$ & 821 & $495(60 \%)$ \\
\hline 2009 & 254 & $97(38 \%)$ & 1,191 & $747(62 \%)$ \\
\hline all 3 surveys & 254 & 17 & & \\
\hline at least one survey & 254 & $142(56 \%)$ & 1,191 & $854(72 \%)$ \\
\hline
\end{tabular}

We present details for Brazil in this Table, and details for India, Korea, and Turkey in the Appendix.

Brazil sample. Number of firms and market capitalization for firms which responded to our Brazil surveys. Market capitalization is based on exchange rate at Dec. 31, 2009 of $\mathrm{R} \$ 1.75 / \mathrm{US} \$ 1$ and is measured at end of each survey year. Last row indicates respondents that were public in 2009 and in the dataset at least once.

TABLE 2

Board Structure Index Elements in Each Country

\begin{tabular}{|c|c|c|c|c|}
\hline ELEMENTS & BRAZIL & INDIA & KOREA & TURKEY \\
\hline \multicolumn{5}{|l|}{$\begin{array}{l}\text { Board structure index } \\
\text { Board independence elements }\end{array}$} \\
\hline$\geq 1$ outside director on board & "b_bs_1 (NP) & NM & $\mathrm{NM}$ & 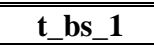 \\
\hline$>1$ outside director & b_bs_2(NP) & NM & NM & t_bs_2 \\
\hline$\geq 30 \%$ outside directors & b_bs_3(NP) & NM & NM & t_bs_3 \\
\hline$\geq 50 \%$ outside directors & b_bs_4 (NP) & i_bs_4 & k_bs_4 & $\mathrm{NM}$ \\
\hline strictly $>50 \%$ outside directors & NM & i_bs_5 & k_bs_5 & NM \\
\hline CEO is NOT board chairman & b_bs_7 & i_bs_7 & NA & t_bs_7 \\
\hline $\begin{array}{l}\text { Board chairman is outside director or firm has } \\
\text { outside lead director }\end{array}$ & NM & NA & k_bs_8 & NM \\
\hline $\begin{array}{l}\geq 50 \% \text { outside directors or } \geq 1 / 3 \text { outside directors } \\
\text { and } \mathrm{CEO} \text { is not chairman }{ }^{17}\end{array}$ & b_bs_9 (NP) & i_bs_9 & NA & NM \\
\hline Audit comm. has outside director & NA & NA & $\mathrm{NM}$ & t_bs_13 \\
\hline Audit comm. has majority of outsiders & NM & i_bs_14 (NP) & $\mathrm{k} \_\mathrm{bs} \_14$ & NA \\
\hline Audit comm. has $2 / 3$ outsiders & NM & i_bs_15 (NP) & k_bs_15 & NA \\
\hline $\begin{array}{l}\text { Permanent fiscal board or audit comm. with } \\
\text { minority shareholder representative exists }\end{array}$ & b_bs_20 & $\mathrm{NM}$ & $\mathrm{NM}$ & $\mathrm{NM}$ \\
\hline \multicolumn{5}{|l|}{ Board committee elements } \\
\hline Audit committee (comm.) exists & b_bs_11 & NM & k_bs_11 & NM \\
\hline Audit comm. has non-executive chair & NA & NA & $\mathrm{NM}$ & t_bs_12 \\
\hline Compensation comm. Exists & NM & i_bs_16 & k_bs_16 & NA \\
\hline Outside director nominating comm. exists & NM & NA & k_bs_17 & NA \\
\hline Corporate Governance comm. Exists & NM & NA & $\mathrm{NM}$ & t_bs_18 \\
\hline Permanent or near-permanent fiscal board exists & b_bs_19 & NM & NM & $\mathrm{NM}$ \\
\hline
\end{tabular}

Table indicates which governance elements we used in each country. In element label, the first letter indicates the country, the next ones the subindex that the element belongs to, and next the number of the element within that subindex (e.g., i_dis_11 is element 11 of Disclosure Subindex, for India). Elements in boldface are used as index elements. An element not boldfaced is available and potentially useful, but is not included in the index because it is too similar to another element that is used. NP (non-public): not publicly available, NA (not available): element is non-public and not collected in our private surveys; NM (not meaningful) because mandatory, not allowed, too rare or too common; We use "outside" and "independent" directors interchangeably. We present details for Board Structure Index in this Table, and details for the remainder of our governance indices in the Appendix. For additional details on the elements, see the expanded working paper version of Black et al. (2014). 
TABLE 3

Summary Statistics and Correlations for Corporate Governance Indices

Panel A. Summary Statistics For Brazil

\begin{tabular}{|l|ccccc|}
\hline & Mean & Median & Std.Dev. & Min & Max \\
\hline Disclosure Index & 78.78 & 90.91 & 24.65 & 18.18 & 100 \\
Board Structure Index & 50.02 & 57.14 & 21.67 & 0 & 100 \\
Ownership Structure Index & 58.95 & 57.44 & 15.95 & 26.31 & 91.30 \\
Board Procedure Index & 66.40 & 66.67 & 25.03 & 0 & 100 \\
Minority Shareholder Rights Index & 46.37 & 57.14 & 26.32 & 0 & 100 \\
Related Party Transactions Index & 64.42 & 80.00 & 30.82 & 0 & 100 \\
Brazil CGI & 60.82 & 63.03 & 13.63 & 20.12 & 90.12 \\
\hline
\end{tabular}

Sample is pooled across years. Indices are non-normalized (0 100). Brazil CGI is average of non-normalized indices.

Panel B. Correlation coefficients

\begin{tabular}{|c|c|c|c|c|c|c|}
\hline & \multicolumn{6}{|c|}{ Brazil } \\
\hline 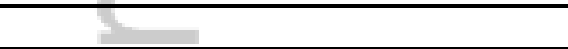 & DS & BS & OWN & $\mathbf{B P}$ & SR & RPT \\
\hline Brazil CGI & $0.76^{* * * *}$ & $0.48^{* * * *}$ & $0.36^{* * *}$ & $0.56^{* * *}$ & $0.70^{* * * *}$ & $0.45^{* * * 4}$ \\
\hline Subindex complement & $0.57^{* * *}$ & $0.24^{* * * *}$ & $0.18^{* *}$ & $0.29^{* * *}$ & $0.47^{* * *}$ & 0.08 \\
\hline Disclosure Index (DS) & & $0.19^{* * *}$ & $0.24^{* *}$ & $0.40^{* * *}$ & $0.61^{* * *}$ & $0.10^{*}$ \\
\hline Board Structure Index (BS) & & & $0.10^{*}$ & $0.28^{* * *}$ & $0.23^{* * * *}$ & 0.05 \\
\hline Ownership Structure Index (OWN) & & & & 0.05 & $0.29^{* * * *}$ & 0.04 \\
\hline Board Procedure Index (BP) & & & & & $0.15^{* * * *}$ & -0.01 \\
\hline Minority Shareholder Rights Index (SR) & & & & & & 0.07 \\
\hline 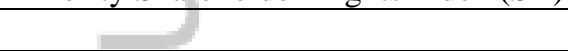 & \multicolumn{6}{|c|}{ India } \\
\hline India CGI & $0.52^{* * * *}$ & $0.44^{* * * *}$ & & $0.55^{* * * *}$ & $0.36{ }^{* * * *}$ & $0.64^{\text {**** }}$ \\
\hline Subindex complement & $0.17^{* * *}$ & $0.09^{* *}$ & & $0.24^{* * *}$ & 0.04 & $0.13^{* * *}$ \\
\hline Disclosure Index (DS) & & 0.039 & & $0.19^{* * *}$ & $0.07^{* *}$ & $0.09^{* *}$ \\
\hline Board Structure Index (BS) & & & & $0.07^{* *}$ & -0.01 & $0.09^{*}$ \\
\hline Board Procedure Index (BP) & & & & & $0.14^{* * * *}$ & $0.17^{* * *}$ \\
\hline Minority Shareholder Rights Index (SR) & & & & & & -0.04 \\
\hline \multicolumn{7}{|l|}{ 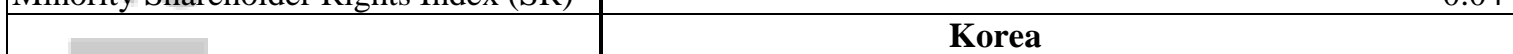 } \\
\hline Korea CGI & $0.75^{* * *}$ & $0.63^{* * *}$ & $0.19^{* * * *}$ & $0.67^{* * *}$ & $0.74^{* * * *}$ & \\
\hline Subindex complement & $0.43^{* * *}$ & $0.51^{* * * *}$ & $-0.09^{* * * *}$ & $0.44^{* * *}$ & $0.46^{* * *}$ & \\
\hline Disclosure Index (DS) & & $0.42^{* * * *}$ & $-0.06^{* * *}$ & $0.36^{* * *}$ & $0.38^{* * * *}$ & \\
\hline Board Structure Index (BS) & & & $-0.06^{* * * *}$ & $0.44^{* * *}$ & $0.39^{* * *}$ & \\
\hline Ownership Structure Index (OWN) & & & & $-0.12^{* * *}$ & $-0.04^{* * * *}$ & \\
\hline Board Procedure Index (BP) & & & & & $0.39^{* * * *}$ & \\
\hline & \multicolumn{6}{|c|}{ Turkey } \\
\hline Turkey CGI & $0.93 * * *$ & $0.65 * *$ & $0.19 * *$ & $0.73 * *$ & $0.35 * *$ & \\
\hline Subindex complement & $0.58 * * *$ & $0.46 * *$ & $0.07 * *$ & $0.62 * * *$ & $0.24 * *$ & \\
\hline Disclosure Index (DS) & & $0.37^{* * * *}$ & $0.05^{*}$ & $\mathbf{0 . 5 2} 2^{* * * *}$ & $0.20 * * *$ & \\
\hline Board Structure Index (BS) & & & 0.01 & $0.43^{* * *}$ & $0.15^{* * *}$ & \\
\hline Ownership Structure Index (OWN) & & & & 0.04 & $0.05^{* *}$ & \\
\hline Board Procedure Index (BP) & & & & & $0.27^{* * * *}$ & \\
\hline
\end{tabular}

Pearson correlation coefficients for non-normalized country CGI, subindices, and "subindex complements" (for each subindex, the complement is country $C G I-$ that subindex). *,**, and *** respectively indicate significance levels at $10 \%, 5 \%$, and $1 \%$ levels. Significant correlations (at $5 \%$ or better) are in bold. 
TABLE 4

Cronbach's $\alpha$ for Country Corporate Governance Indices and Subindices

\begin{tabular}{|c|c|c|c|c|c|}
\hline & & Brazil & India & Korea & Turkey \\
\hline \multirow{3}{*}{ A. All governance elements } & Cronbach $\alpha$ & 0.80 & 0.70 & 0.76 & 0.94 \\
\hline & Mean $r$ & 0.09 & 0.05 & 0.10 & 0.25 \\
\hline & No. of elements & $(43)$ & $(42)$ & $(27)$ & $(44)$ \\
\hline \multirow{3}{*}{ B. All subindices } & Cronbach $\alpha$ & 0.56 & 0.31 & 0.50 & 0.58 \\
\hline & Mean $r$ & 0.18 & 0.08 & 0.20 & 0.22 \\
\hline & No. of elements & $(6)$ & $(5)$ & $(4)$ & $(5)$ \\
\hline \multirow{3}{*}{ C. Board Structure Subindex } & Cronbach $\alpha$ & 0.50 & 0.38 & 0.74 & 0.75 \\
\hline & Mean $r$ & 0.13 & 0.09 & 0.29 & 0.34 \\
\hline & No. of elements & $(7)$ & $(6)$ & $(7)$ & $(6)$ \\
\hline \multirow{3}{*}{ D. Board Procedure Subindex } & Cronbach $\alpha$ & 0.58 & 0.56 & 0.49 & 0.61 \\
\hline & Mean $r$ & 0.19 & 0.09 & 0.07 & 0.24 \\
\hline & No. of elements & $(6)$ & $(13)$ & $(12)$ & $(5)$ \\
\hline \multirow{3}{*}{ E. Disclosure Subindex } & Cronbach $\alpha$ & 0.84 & 0.69 & 0.43 & 0.86 \\
\hline & Mean $r$ & 0.32 & 0.15 & 0.20 & 0.21 \\
\hline & No. of elements & $(11)$ & $(13)$ & $(3)$ & $(23)$ \\
\hline \multirow{3}{*}{ F. Ownership Structure Subindex } & Cronbach $\alpha$ & 0.64 & & - & 0.40 \\
\hline & Mean $r$ & 0.26 & & & 0.10 \\
\hline & No. of elements & $(5)$ & & $(1)$ & $(6)$ \\
\hline \multirow{3}{*}{ G. Shareholder Rights Subindex } & Cronbach $\alpha$ & 0.68 & 0.11 & 0.33 & 0.42 \\
\hline & Mean $r$ & 0.23 & 0.03 & 0.14 & 0.15 \\
\hline & No. of elements & $(7)$ & (4) & $(3)$ & $(4)$ \\
\hline \multirow{3}{*}{ H. RPTs Subindex } & Cronbach $\alpha$ & 0.77 & 0.77 & & \\
\hline & Mean $r$ & 0.32 & 0.36 & & \\
\hline & No. of elements & (7) & (6) & & \\
\hline
\end{tabular}

Table shows Cronbach's a (top row), mean correlation ( $r$ ) between elements (middle row) and number of elements (in parentheses) for corporate governance elements, indices, and their subindices. There is no Cronbach's $\alpha$ for the ownership structure subindex in Korea, because the subindex has only one element. 
TABLE 5

Principal Component Analysis (PCA)

Panel A. Subindex Components for All Countries

\begin{tabular}{|c|c|c|c|c|c|c|c|c|}
\hline & Eigenvalue & $\begin{array}{c}\text { Explained } \\
\text { Variance }\end{array}$ & $\begin{array}{c}\text { Board } \\
\text { Structure }\end{array}$ & $\begin{array}{c}\text { Board } \\
\text { Procedure }\end{array}$ & Disclosure & $\begin{array}{l}\text { Ownership } \\
\text { Structure }\end{array}$ & $\begin{array}{l}\text { hareholder } \\
\text { Rights }\end{array}$ & RPTs \\
\hline \multicolumn{9}{|l|}{ Brazil } \\
\hline Component 1 & 2.08 & $34.6 \%$ & 0.448 & 0.575 & 0.860 & 0.399 & 0.790 & 0.173 \\
\hline Component 2 & 1.19 & $19.8 \%$ & -0.655 & -0.435 & 0.074 & 0.708 & 0.224 & 0.118 \\
\hline \multicolumn{9}{|l|}{ India } \\
\hline Component 1 & 1.37 & $24.7 \%$ & 0.568 & 0.439 & 0.323 & -0.284 & 0.730 & 1.37 \\
\hline Component 2 & 1.08 & $24.5 \%$ & -0.122 & 0.597 & 0.543 & 0.748 & -0.009 & 1.08 \\
\hline \multicolumn{9}{|l|}{ Korea } \\
\hline Component 1 & 2.24 & $44.8 \%$ & 0.767 & 0.751 & 0.722 & -0.179 & 0.730 & 2.24 \\
\hline \multicolumn{9}{|l|}{ Turkey } \\
\hline Component 1 & 2.04 & $40.9 \%$ & 0.730 & 0.812 & 0.802 & -0.007 & 0.445 & \\
\hline Component 2 & 1.00 & $20.1 \%$ & -0.095 & 0.046 & 0.029 & 0.957 & 0.305 & \\
\hline
\end{tabular}

Panel B. Individual Element Components for Brazil

\begin{tabular}{|c|c|c|c|c|c|}
\hline Variable & Component 1 & Component 2 & Component 3 & Component 4 & Component 5 \\
\hline Eigenvalue & 4.53 & 4.28 & 3.83 & 2.61 & 2.32 \\
\hline Explained Variance & $10.5 \%$ & $9.9 \%$ & $8.9 \%$ & $6.0 \%$ & $5.4 \%$ \\
\hline \multicolumn{6}{|c|}{ Board Structure (7) } \\
\hline b_bs_1 & -0.007 & 0.074 & 0.025 & 0.949 & -0.015 \\
\hline b_bs_3 & -0.007 & 0.074 & 0.025 & 0.949 & -0.015 \\
\hline b_bs_4 & -0.016 & -0.121 & -0.152 & 0.683 & 0.080 \\
\hline \multicolumn{6}{|c|}{ Board Procedures (6) } \\
\hline b_bp_13 & 0.460 & 0.022 & -0.072 & -0.054 & -0.037 \\
\hline \multicolumn{6}{|c|}{ Disclosure (11) } \\
\hline b_dis_2 & 0.689 & 0.313 & 0.036 & -0.098 & 0.020 \\
\hline b_dis_3 & 0.815 & 0.129 & -0.035 & 0.022 & 0.127 \\
\hline b_dis_4 & 0.417 & 0.236 & 0.032 & 0.062 & -0.151 \\
\hline b_dis_5 & 0.836 & 0.229 & 0.042 & -0.001 & 0.081 \\
\hline b_dis_7 & 0.627 & 0.492 & -0.008 & -0.050 & 0.120 \\
\hline b_dis_8 & 0.709 & 0.303 & -0.012 & 0.039 & -0.013 \\
\hline b_dis_9 & 0.467 & 0.611 & 0.019 & -0.002 & 0.138 \\
\hline b_dis_17 & 0.567 & 0.597 & 0.001 & -0.030 & 0.019 \\
\hline \multicolumn{6}{|c|}{ Ownership Structure (5) } \\
\hline b_own_2 & 0.065 & 0.432 & -0.116 & -0.038 & 0.439 \\
\hline b_own_3 & 0.074 & 0.208 & -0.052 & -0.088 & 0.649 \\
\hline b_own_5 & 0.081 & 0.197 & -0.086 & -0.005 & 0.768 \\
\hline \multicolumn{6}{|c|}{ Shareholder Rights (7) } \\
\hline b_sr_12 & 0.280 & 0.779 & 0.043 & 0.067 & 0.213 \\
\hline b_sr_13 & 0.195 & 0.753 & 0.063 & 0.146 & 0.190 \\
\hline b_sr_14 & 0.277 & 0.797 & -0.032 & -0.001 & 0.282 \\
\hline b_sr_16 & 0.101 & 0.650 & -0.047 & 0.108 & -0.057 \\
\hline \multicolumn{6}{|c|}{ RPT (7) } \\
\hline b_rpt_1 & -0.006 & -0.021 & 0.980 & 0.005 & -0.027 \\
\hline b_rpt_2 & -0.006 & -0.021 & 0.980 & 0.005 & -0.027 \\
\hline b_rpt_3 & -0.006 & -0.021 & 0.980 & 0.005 & -0.027 \\
\hline b_rpt_8 & -0.131 & 0.060 & 0.624 & 0.013 & 0.024 \\
\hline
\end{tabular}


Panel A: Loadings of each subindex for the two components retained in PCA for all four countries. Panel B: the loadings of each governance element for the five components of Brazil CGI with the highest eigenvalues. We report only the elements with loading above 0.4 in at least one of the five main components. Both panels: We use varimax rotation. Loadings above 0.4 are in boldface. Elements are described in Table 2 and the corresponding Appendix table.

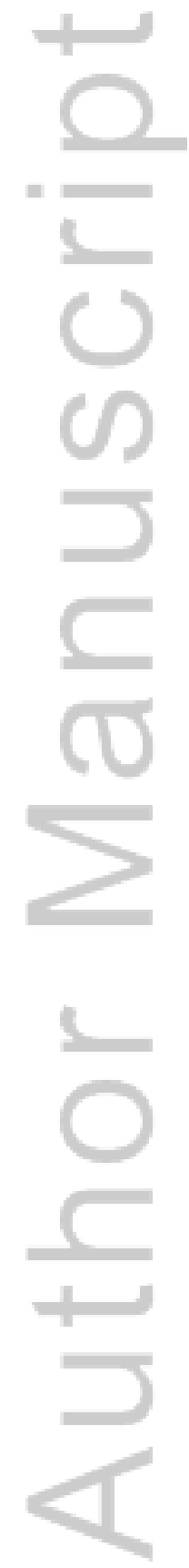


TABLE 6

Governance Components, Subindices and Firm Value across Countries

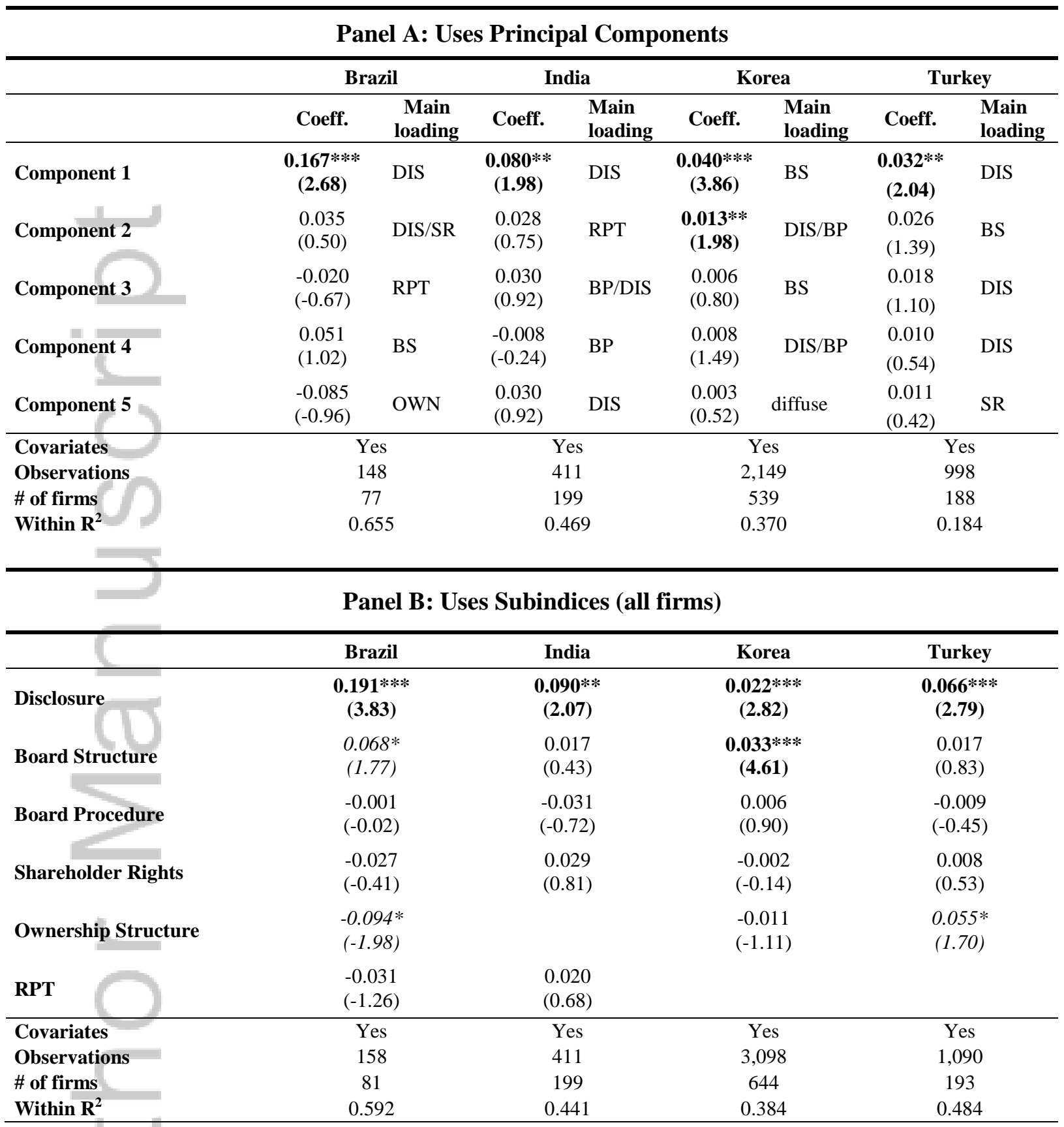




\section{Panel C: Uses Subsubindices for Board Independence and Board Committees}

\begin{tabular}{|c|c|c|c|c|}
\hline & Brazil & India & Korea & Turkey \\
\hline Disclosure & $\begin{array}{c}0.172 * * * \\
(3.36)\end{array}$ & $\begin{array}{c}0.090 * * \\
(2.04)\end{array}$ & $\begin{array}{l}\mathbf{0 . 0 2 0} * * * \\
(\mathbf{2 . 7 3})\end{array}$ & $\begin{array}{c}\mathbf{0 . 0 6 2} * * \\
(2.58)\end{array}$ \\
\hline Board Independence & $\begin{array}{c}0.092 * * \\
(2.61)\end{array}$ & $\begin{array}{l}0.012 \\
(0.32)\end{array}$ & $\begin{array}{l}0.019 * * * \\
(3.08)\end{array}$ & $\begin{array}{c}0.036 * \\
(1.89)\end{array}$ \\
\hline Board Committees & $\begin{array}{l}-0.008 \\
(-0.17)\end{array}$ & $\begin{array}{l}0.011 \\
(0.35)\end{array}$ & $\begin{array}{c}0.015 * * \\
(2.37)\end{array}$ & $\begin{array}{l}-0.021 \\
(-1.07)\end{array}$ \\
\hline Board Procedure & $\begin{array}{l}-0.007 \\
(-0.21)\end{array}$ & $\begin{array}{l}-0.032 \\
(-0.72)\end{array}$ & $\begin{array}{l}0.004 \\
(0.59)\end{array}$ & $\begin{array}{l}-0.006 \\
(-0.33)\end{array}$ \\
\hline Shareholder Rights & $\begin{array}{l}-0.017 \\
(-0.27)\end{array}$ & $\begin{array}{l}0.028 \\
(0.81)\end{array}$ & $\begin{array}{l}-0.000 \\
(-0.03)\end{array}$ & $\begin{array}{l}0.003 \\
(0.19)\end{array}$ \\
\hline Ownership Structure & $\begin{array}{c}-0.098 * * \\
(-2.00)\end{array}$ & & $\begin{array}{l}-0.012 \\
(-1.56)\end{array}$ & $\begin{array}{c}0.056^{*} \\
(1.75)\end{array}$ \\
\hline RPT & $\begin{array}{l}-0.027 \\
(-1.26) \\
\end{array}$ & $\begin{array}{l}0.019 \\
(0.67) \\
\end{array}$ & & \\
\hline Covariates & Yes & Yes & Yes & Yes \\
\hline Observations & 158 & 411 & 3,098 & 1,090 \\
\hline \# of firms & 81 & 199 & 644 & 193 \\
\hline Within $\mathbf{R}^{2}$ & 0.592 & 0.441 & 0.384 & 0.484 \\
\hline
\end{tabular}

Panel A. Firm fixed effects regressions of $\ln$ (Tobin's $q$ ) on either five principal components, covariates (listed in Table 4, coefficients suppressed) and constant term. Sample includes only firm-years with complete data on all elements. Panel B replaces principal components with subindices and uses full sample (for firm-years with missing elements, we build subindices using the average of the nonmissing elements of each subindex). Panel $\mathrm{C}$ is similar to Panel D, but separates Board Structure Subindex into Board Independence and Board Committees subsubindices. Observations are excluded as outliers if a studentized residual from regressing $\ln$ (Tobin's $q$ ) on $C G I$, year-by-year $> \pm 1.96$. $t$-statistics, using firm clusters, are in parentheses. *,**, and *** respectively indicate significance levels at $10 \%, 5 \%$, and $1 \%$ levels. Significant results (at 5\% level or better) are in boldface; marginally significant results (at 10\% level) in italics.

\section{FIGURE 1}

Histogram of Governance Element Correlations: Brazil 


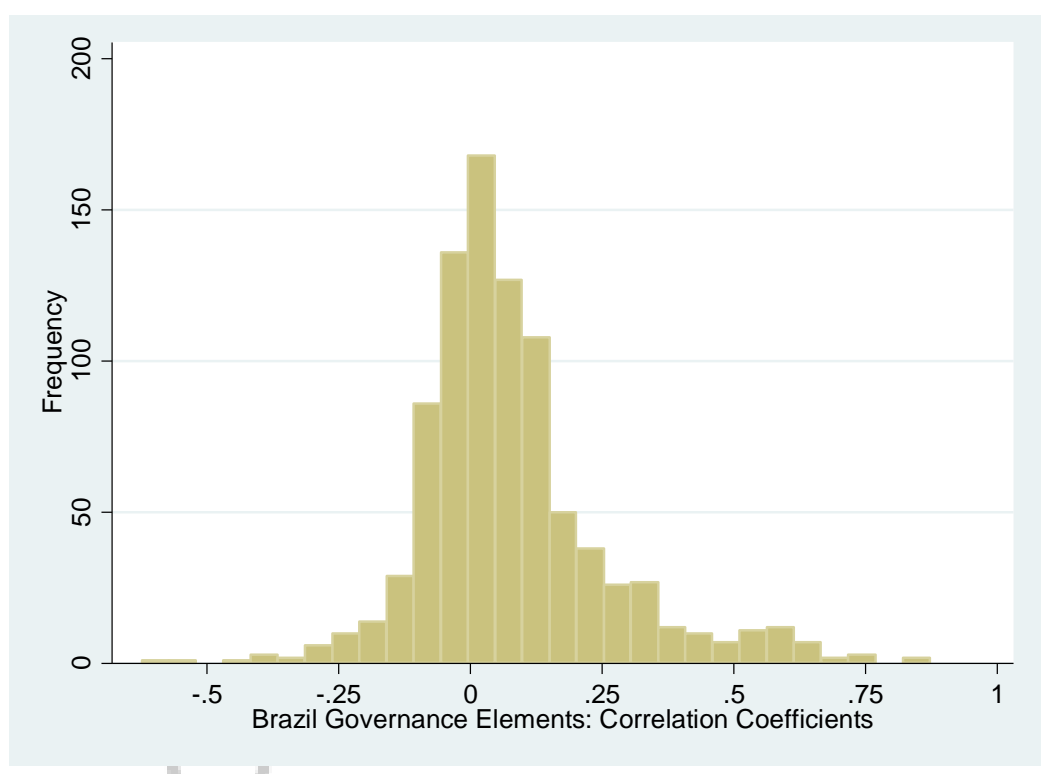

Histogram shows the frequency distribution for the correlations between the 43 elements of Brazil Corporate Governance Index (BCGI). The minimum (maximum) correlation is $-0.62(+0.87)$. The mean (median) value of the absolute values of the correlations is $0.13(0.08)$.

\section{Notes:}

${ }^{1}$ For background on construct validity, see Shadish, Cook and Campbell (2002). Strauss \& Smith (2009) review more recent literature on construct validity.

${ }^{2}$ Linck, Netter and Yang (2008), Beekes, Hong and Owen (2010), and Lei and Song (2012) employ some of the methods we use. However, their principal focus is to reduce the dimensionality of their governance data.

${ }^{3}$ These studies include, e.g., Aggarwal, Erel, Stulz and Williamson (2006); Klapper and Love (2004); Durnev and Kim (2005) and Doidge, Karolyi and Stulz (2007).

${ }^{4}$ A good general reference for Cronbach's $\alpha$ is Nunnally and Bernstein (1994).

${ }^{5}$ A good general reference for PCA is Jolliffe (2008).

${ }^{6}$ Detailed information on our data sources, samples, and their representativeness can be found in Black et al. (2015). The Brazil, India, and Korea surveys are available on request. 
${ }^{7}$ The exceptions are principally in the Ownership Structure Subindex.

${ }^{8}$ Some studies suggest that inter-item correlations should be as high as possible to constitute a good index (Horst, 1966: 147). Others disagree and recommend smaller values. Briggs and Cheek (1986), for example, argue that the optimal balance between bandwidth and homogeneity of an index occurs when the mean inter-item correlations are in the range [0.2-0.4]. Clark and Watson (1995: 316) recommend inter-item correlations in the range of [0.15-0.20] for broad higher order constructs, and higher values, [0.40-0.50], for narrower constructs.

${ }^{9}$ Our discussion of Cronbach's $\alpha$ assumes that one starts with an index, and then measures $\alpha$. One can also use the relative $\alpha$ values from different possible indices to choose between them. That effort, too, is fraught with challenges (Nunnally and Bernstein, 1994).

${ }^{10}$ See Black, Jang and Kim (2006, Korea), Balasubramian, Black and Khanna (2010, India); Ararat, Black, and Yurtoglu (2015, Turkey).

11 The mean (median) absolute value of the pairwise correlations is $0.11(0.05)$ for India and 0.11 (0.09) for Korea.

12 The higher correlations in Turkey may stem from Turkey's comply-or-explain corporate governance code, adopted in 2006. Many firms adopt most of the code elements, so these elements are strongly correlated.

13 An analogy may be useful. Suppose that one seeks to measure mathematical ability, through tests of arithmetic, algebra, geometry, calculus, and statistics, for students who have taken all five subjects. If math ability is a coherent concept, we would expect a major retained component, often the first component to load broadly on most or all of the subject-specific tests.

14 The sample is larger than in Panel A because we can compute subindices based on non-missing elements, as described above.

15 In Brazil Disclosure Subindex has coeff. $=0.191 ; t=3.83$; while Component 1 , which loads only on Disclosure, has coeff. $=0.168 ; t=2.68$. In Korea, Disclosure Subindex has coeff. $=0.022 ; t$ = 2.82; while Component 2, which loads on Board Procedure and Disclosure, has coeff. = 0.013; $t=1.98$. 
16 Appendix Table App-7 presents results for subindices computed using only firm-year observations with no missing elements - thus the same sample as in Panel A. The principal differences from Panel B are: in Korea, Disclosure Index loses significance for Korea, while Board Procedure takes a positive and statistically significant coefficient; in Brazil, the coefficient on Board Structure Index strengthens and is statistically significant (versus marginally significant in Panel B).

${ }^{17}$ This element is required by India's “Clause 49"; however, not all firms comply.

This article is protected by copyright. All rights reserved. 


\section{Short bio}

Burcin Yurtoglu is Professor of Finance at WHU - Otto Beisheim School of Management. He holds a doctoral degree in Economics from the University of Vienna. His research interests include corporate governance, corporate finance and competition policy with a focus on emerging markets.

Vikramaditya Khanna is William W. Cook Professor of Law at the University of Michigan Law School. He holds an S.J.D. from Harvard Law School. His principal research interests include corporate and securities laws, law in India, corporate crime, the globalizing legal profession, comparative corporate governance, and law and economics. His publications include papers in the Harvard Law Review, Journal of Finance, Journal of Econometrics, Journal of Law, Economics and Organization, Michigan Law Review, Supreme Court Economic Review, and Georgetown Law Journal.

Bernard S. Black is Nicholas D. Chabraja Professor at Northwestern University, Pritzker School of Law, Institute for Policy Research, and Kellogg School of Management (Finance Department). He holds a B.A. from Princeton University, an M.A. in physics from University of California at Berkeley and a J.D. from Stanford Law School. His principal research areas include health policy and medical malpractice, law and finance, international corporate governance, and corporate and securities law.

Woochan Kim is a Professor of Finance at Korea University Business School and a Research Associate at the European Corporate Governance Institute (ECGI). He holds a Ph.D. degree in Public Policy from Harvard University. Dr. Kim's current area of research includes corporate governance, pension fund management, foreign portfolio investors, and FX risk management. His publications appear in the Journal of Financial Economics, the Journal of Law, Economics, and Organization, the Journal of International Economics, the Journal of Corporate Finance, and many others. Outside of school, he serves as the Director of Economic Reform Research Institute (ERRI).

Antonio Gledson de Carvalho is Professor of Finance at Fundacao Getulio Vargas - Sao Paulo Business School. He holds a PhD in Economics and Master in Mathematics from the University of Illinois. His principal research interests include corporate finance, corporate governance, capital markets and venture capital. His publications include papers in the Journal of Econometrics and Journal of Corporate Finance.

\section{Corresponding author}

Address for correspondence: Bernard S. Black, Pritzker School of Law, Northwestern University, 375 East Chicago Ave, Chicago IL 60611, USA. E-mail: bblack@ northwestern.edu. 